\title{
Apolipoprotein E, Not Fibrillar $\beta$-Amyloid, Reduces Cerebral Glucose Metabolism in Normal Aging
}

\author{
William J. Jagust ${ }^{1,2}$ and Susan M. Landau, ${ }^{1,2}$ For the Alzheimer's Disease Neuroimaging Initiative \\ ${ }^{1}$ Helen Wills Neuroscience Institute, University of California at Berkeley, Berkeley, California 94720, and ${ }^{2}$ Life Sciences Division, Lawrence Berkeley \\ National Laboratory, Berkeley California 94720
}

The $\varepsilon 4$ allele of the polymorphic apolipoprotein $\mathrm{E}$ gene is associated with increased risk of Alzheimer's disease (AD), deposition of $\beta$-amyloid $(\mathrm{A} \beta)$, and reduction in cerebral glucose metabolism in asymptomatic people. Although ApoE4 may exert an effect on AD risk through amyloidogenic pathways, whether its effect on glucose metabolism is related to $\mathrm{A} \beta$ is unknown. To answer this question, we examined data from 175 cognitively normal older people (mean age, 77; 87 men, 88 women) in the Alzheimer's disease neuroimaging initiative studied concurrently with $\left[{ }^{18} \mathrm{~F}\right]$ flurodeoxyglucose (FDG) positron emission tomography measures of glucose metabolism and the radiotracer $\left[{ }^{18} \mathrm{~F}\right]$ florbetapir, an imaging agent which labels fibrillar $\mathrm{A} \beta$ in vivo. Based on a threshold value of florbetapir uptake determined in separate samples, subjects were categorized as florbetapir + or florbetapir - . Glucose metabolism was measured as a continuous variable in a group of regions of interest (ROIs) selected $a$ priori based on their involvement in $\mathrm{AD}$, and also by using a whole-brain voxelwise approach. Among this sample, $29 \%$ of subjects were florbetapir + and $23 \%$ were ApoE 4 carriers. As expected, there was a significant association between ApoE4 genotype and florbetapir positivity. Florbetapir status, however, was not significantly associated with glucose metabolism, but the ApoE4 genotype was associated with lower metabolism in both voxelwise and ROI approaches. These results show that ApoE genotype, and not aggregated fibrillar forms of $A \beta$, contributes to reduced glucose metabolism in aging and adds to a growing list of neural consequences of $\mathrm{ApoE}$ that do not appear to be related to $\mathrm{A} \beta$.

\section{Introduction}

The $\varepsilon 4$ allele of the polymorphic apolipoprotein E gene (ApoE4) is a major risk factor for Alzheimer's disease (AD) (Corder et al., 1993; Schellenberg, 1995). This polymorphism affects clearance of the $\beta$-amyloid $(\mathrm{A} \beta)$ protein that is proposed to play a major role in AD pathogenesis (Castellano et al., 2011). The ApoE4 allele is also associated with increased aggregation of $\mathrm{A} \beta$ into toxic oligomeric forms (Ma et al., 1994; Näslund et al., 1995) and

\section{Received July 9, 2012; revised 0ct. 10, 2012; accepted 0ct. 18, 2012.}

Author contributions:W.J. and S.M.L. designed research; W.J. performed research;W.J. and S.M.L. analyzed data; W.J. and S.M.L. wrote the paper.

Data collection and sharing for this project was funded by the Alzheimer's Disease Neuroimaging Initiative (ADNI) (NIH Grant U01 AG024904). ADNI is funded by the National Institute on Aging, the National Institute of Biomedical Imaging and Bioengineering, and through generous contributions from the following: Abbott; Alzheimer's Association; Alzheimer's Drug Discovery Foundation; Amorfix Life Sciences; AstraZeneca; Bayer HealthCare; BioClinica; Biogen Idec; Bristol-Myers Squibb; Eisai;Elan Pharmaceuticals; Eli Lilly; F. Hoffmann-La Roche and its affiliated company, Genentech; GE Healthcare; Innogenetics; Janssen Alzheimer Immunotherapy Research \& Development; Johnson \& Johnson Pharmaceutical Research \& Development; Medpace; Merck; Meso Scale Diagnostics; Novartis Pharmaceuticals Corporation; Pfizer; Servier; Synarc; and Takeda Pharmaceuticals. The Canadian Institutes of Health Research is providing funds to support ADNI clinical sites in Canada. Private sector contributions are facilitated by the Foundation for the National Institutes of Health (www.fnih.org). The grantee organization is the Northern California Institute for Research and Education, and the study is coordinated by the Alzheimer's Disease Cooperative Study at the University of California, San Diego, CA. ADNI data are disseminated by the Laboratory for Neuro Imaging at the University of California, Los Angeles, CA. Data used in preparation of this article were obtained from the Alzheimer's Disease Neuroimaging Initiative (ADNI) database (adni.loni.ucla.edu). As such, the investigators within the ADNI contributed to the design and implementation of ADNI and/or provided data but did not participate in analysis or writing of this report. A complete listing of ADNI investigators can be found at: http://adni.loni.ucla. edu/wp-content/uploads/how_to_apply/ADNI_Acknowledgement_List.pdf.

Correspondence should be addressed to William Jagust, Helen Wills Neuroscience Institute, 132 Barker Hall, University of California, Berkeley, CA 94720-3190. E-mail: jagust@berkeley.edu.

DOI:10.1523/JNEUROSCI.3266-12.2012

Copyright $\odot 2012$ the authors $\quad 0270-6474 / 12 / 3218227-07 \$ 15.00 / 0$ greater deposition of $\mathrm{A} \beta$ in amyloid plaques seen at autopsy in human brains (Rebeck et al., 1993; Schmechel et al., 1993). These postmortem results have been extended by in vivo human studies that used positron emission tomography (PET) with radiolabeled ligands that bind to fibrillar $\mathrm{A} \beta$ to demonstrate increased $\mathrm{A} \beta$ deposition in cognitively normal older people carrying the ApoE4 allele (Reiman et al., 2009; Morris et al., 2010; Fleisher et al., 2011).

$\mathrm{AD}$ is also associated with reductions in cerebral glucose metabolism that can be measured with $\left[{ }^{18} \mathrm{~F}\right]$ flurodeoxyglucose PET (FDG-PET) and appear primarily in lateral and medial parietal and lateral temporal cortex (Silverman et al., 2001). Older asymptomatic ApoE4 carriers also show reductions in glucose metabolism that spatially overlap with those seen AD patients (Small et al., 1995; Reiman et al., 1996). These reports appear consistent with the ApoE effects on $\mathrm{A} \beta$, suggesting that genetic effects may be mediated by deposition of $\mathrm{A} \beta$ that then results in synaptic dysfunction (Lacor et al., 2007), reducing cortical metabolism. However, the ApoE4 allele is also associated with similar metabolic reductions in individuals at the young ages of 20-39 (Reiman et al., 2004), when A $\beta$ plaque deposition is rare (Braak and Braak, 1997; Kok et al., 2009). This raises the question as to whether metabolic alterations seen in older ApoE4 carriers are due to $\mathrm{A} \beta$ deposition or another process.

The ApoE gene, in fact, has a multiplicity of neural effects that are not necessarily related to its role in association with $\mathrm{A} \beta$ (Kim et al., 2009). This includes effects on synaptic plasticity and repair (Slezak and Pfrieger, 2003) and on synaptic development (Ji et al., 2003; Levi et al., 2003; Dumanis et al., 2009). Functional MRI 
(fMRI) studies of neural activity in young adults with the ApoE4 allele have largely, although not invariably, showed increases in brain activation during cognitive tasks (Trachtenberg et al., 2012) that are also suggestive of possible synaptic alterations at ages when $A \beta$ deposition is unlikely. In cognitively normal older adults, both increases and decreases in brain activation during cognition have been reported with ApoE4 (Bookheimer et al., 2000; Lind et al., 2006); until recently, such results have been difficult to interpret due to the possibility of concomitant unmeasured $\mathrm{A} \beta$. In the present report, we studied a group of cognitively normal older people who were part of the Alzheimer's disease neuroimaging initiative (ADNI) and who had been examined with both FDG-PET and PET amyloid imaging to differentiate the contributions of $\mathrm{A} \beta$ and $\mathrm{ApoE}$ genotype to resting glucose metabolism.

\section{Materials and Methods}

Subjects. ADNI is a longitudinal multisite study supported by the National Institutes of Health, private pharmaceutical companies, and nonprofit organizations with $\sim 50$ medical center and university sites across the United States and Canada (www.loni.ucla.edu/ADNI). Individuals are recruited and followed longitudinally with imaging (FDG-PET and MRI), cognitive assessments, and blood and CSF biomarkers. In the second phase of ADNI, PET amyloid imaging with the $\left[{ }^{18} \mathrm{~F}\right]$-labeled amyloid imaging agent florbetapir (Clark et al., 2011) was added to the protocol. The subjects of this report are 175 cognitively normal ADNI participants who had available FDG-PET, ApoE genotyping, and $\left[{ }^{18} \mathrm{~F}\right]$ Florbetapir-PET as of June 2012. Full inclusion/exclusion criteria can be found at www.adni-info.org, but briefly, all normal subjects had a clinical dementia rating (CDR; Morris, 1993) of 0, did not present with cognitive complaints, and scored normally on a range of cognitive tests.

FDG-PET. Methods for FDG-PET data acquisition and analysis have been published previously (Jagust et al., 2009; Landau et al., 2011). FDG scans were acquired between 30 and $60 \mathrm{~min}$ after injection of $\sim 5 \mathrm{mCi}$ of tracer. Images underwent a rigorous quality control protocol and were processed to produce final images with standard orientation, voxel size, and $8 \mathrm{~mm}$ resolution (Jagust et al., 2010).

The initial approach to image analysis used a group of regions of interest (ROIs) that were derived from a literature review as described previously (Landau et al., 2011). In brief, we found published papers listing Talairach coordinates representing areas in which FDG uptake differed significantly between $\mathrm{AD}$ patients and normal subjects. Intensity values were generated for each study representing the size of group differences, mapped into Talairach coordinates, superimposed, transformed into z-scores, smoothed, intensity normalized, and thresholded. These regions correspond to areas in left and right hemispheres of temporal, lateral parietal, and medial parietal cortex in which AD-normal differences were maximal (Fig. 2) and which we use as a single composite ROI averaged together. For this study, FDG uptake from this composite $\mathrm{AD}$ signature ROI, normalized to a reference region of cerebellar vermis and pons, comprised the dependent measure of cerebral glucose metabolism that was extracted from PET data using the ROI template and brain images transformed to standard MNI coordinates using SPM5. While we did not use FDG-PET data in dichotomous form, in a previous study values below 1.22 differentiated $\mathrm{AD}$ patients from controls with the best overall accuracy (Landau et al., 2010).

Florbetapir-PET. $\left[{ }^{18} \mathrm{~F}\right]$ Florbetapir and FDG-PET were generally performed within a week of one another. Florbetapir scans were acquired $50-70$ min after injection of $\sim 10 \mathrm{mCi}$ of tracer. Images underwent quality control and processing steps similar to those of the FDG-PET data. Scans were analyzed in native space using the subjects' MRI images (one or usually two averaged MPRAGE images acquired close to the time of the florbetapir scans) that were segmented into cortical regions using Freesurfer version 4.5.0 (surfer.nmr.mgh.harvard.edu/). These cortical ROIs were used to extract florbetapir uptake from gray matter in lateral and medial frontal, anterior, and posterior cingulate, lateral parietal, and lateral temporal cortex. Values were normalized to florbetapir uptake in
Table 1. Participant characteristics

\begin{tabular}{llllll}
\hline & $\begin{array}{l}\text { Total sample } \\
(N=175)\end{array}$ & $\begin{array}{l}\text { ApoE4+ } \\
(N=40)\end{array}$ & $\begin{array}{l}\text { ApoE4- } \\
(N=135)\end{array}$ & $\begin{array}{l}\text { Florbetapir }+ \\
(N=50)\end{array}$ & $\begin{array}{l}\text { Florbetapir- } \\
(N=125)\end{array}$ \\
\hline Age & $77.2(6.0)$ & $76.8(5.6)$ & $77.3(6.1)$ & $78.3(4.8)$ & $76.7(6.4)$ \\
Sex (M/F) & $87 / 88$ & $20 / 20$ & $67 / 68$ & $22 / 28$ & $65 / 60$ \\
Education $^{\text {MMSE }}$ & $16.3(2.8)$ & $15.9(2.9)$ & $16.5(2.7)$ & $16(3)$ & $16.5(2.7)$ \\
ADAS-Cog $^{b}$ & $29(1.2)$ & $28.6(1.3)$ & $29.1(1.2)$ & $29(1.2)$ & $29(1.2)$ \\
ApoE2 carriers $^{c}$ & 23 & 1 & 22 & 4 & $6(3.1)$ \\
\hline
\end{tabular}

${ }^{a} \mathrm{ApoE} 4-$ has significantly higher MMSE than ApoE4+ $(t=2.35, p=0.02)$.

${ }^{b}$ Alzheimer's Disease Assessment Scale- cognitive subscale.

${ }^{C A p o E} 2$ is more common with ApoE4 - than ApoE4 $+\left(\chi^{2}=5.1, p=0.02\right)$.

the whole cerebellum. The averaged cortical uptake in this composite ROI was used as the index of florbetapir uptake in each subject.

Subjects were characterized as florbetapir positive or negative as described previously (Landau et al., 2012). A threshold value of 1.10 for the cortical/cerebellar ratio in a separate study represented the upper limit of the $95 \%$ confidence interval for a group of normal young subjects (Joshi et al., 2012) and was also the value below which no pathological evidence of plaque $\mathrm{A} \beta$ deposition greater than "low likelihood" was found in an imaging-autopsy correlation study (Clark et al., 2011). To account for processing differences between those studies and the methods used here, a separate data set was processed with both methods, yielding a regression equation $(y=0.80 x+0.23)$ that permitted conversion of the 1.10 threshold to a value of 1.11 , which we applied to the current dataset to define $A \beta$ positivity.

Statistics. Both florbetapir and ApoE genotype were independent binary categorical variables. Glucose metabolism, measured in the composite ROI, was the dependent measure as a continuous variable. The initial linear model evaluating these relationships included age as a covariate; a subsequent model included additional potentially confounding variables and variables of interest. The relationship between florbetapir and glucose metabolism was also analyzed as a continuous function using nonparametric statistics because of the non-normality of the florbetapir distribution. ApoE homozygosity was ignored in all analyses. All statistical tests were considered significant at $p<0.05$, and two-tailed test results are reported. Statistical analyses used SPSS 20.

Because the selected ROIs were small (see Fig. 2), and to investigate potentially larger regions of hypometabolism that might have been missed, we followed the ROI analysis with a whole-brain voxelwise analysis using SPM5 to examine the effects of both genotype and $\mathrm{A} \beta$ on glucose metabolism. Voxelwise FDG images in MNI coordinate space were used to carry out an ANOVA with florbetapir and ApoE genotype as binary categorical independent variables, and age as a variable of no interest (as in the FDG ROI model described above). Voxelwise results were initially displayed at $p<0.05$ (uncorrected) to illustrate global patterns, but subsequently were corrected for multiple dependent comparisons at cluster corrected $p<0.001$ (cluster peak threshold, $p<0.001$; extent threshold, $k=210$ ). This was derived from the image volume, degrees of freedom, and image smoothness using Gaussian random field theory (Cao and Worsley, 2001).

\section{Results}

Subject characteristics are reported in Table 1. Forty subjects were carriers of the ApoE4 allele; all but three were heterozygotes for an overall allele frequency of 0.12. ApoE2 alleles were significantly more common in ApoE4 noncarriers. Fifty subjects $(28.6 \%)$ were categorized as florbetapir + . The group as a whole was evenly distributed between men and women. Besides the ApoE2 distribution, the only other significant group differences when subjects were compared by either genotype or florbetapir status was for the Mini-Mental State Examination (MMSE); ApoE4 carriers had slightly but significantly lower mean scores than noncarriers. Of the ApoE4 carriers, 20 $(50 \%)$ were florbetapir+, and of the noncarriers $30(22 \%)$ 


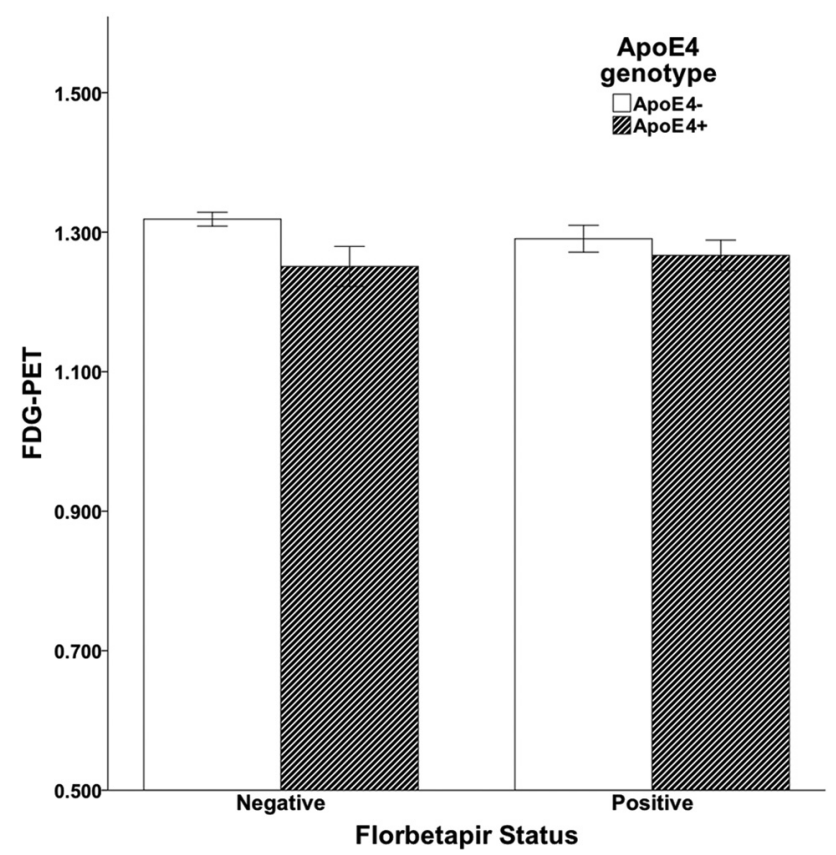

Figure 1. Relationships between florbetapir positivity, ApoE carrier status, and glucose metabolism (FDG-PET). Analysis indicates a significant effect of ApoE, but no effect of florbetapir.

were florbetapir + , a significant association of genotype with $\mathrm{A} \beta\left(\chi^{2}=11.7, p=0.001\right)$.

Glucose metabolism in the composite ROI was inversely associated with age $(r=-0.19, p=0.01)$ and was also lower in ApoE4 carriers $($ mean $=1.26, \mathrm{SD}=0.11)$ than noncarriers $($ mean $=$ $1.31, \mathrm{SD}=0.10)$, a statistically significant difference $(t=2.83$, $p=0.005)$. There was no significant difference $(t=1.5, p=0.14)$ in glucose metabolism between those who were florbetapir+ $($ mean $=1.28, \mathrm{SD}=0.10)$ and florbetapir $-($ mean $=1.31, \mathrm{SD}=$ 0.11 ). There was also no relationship between glucose metabolism and florbetapir as a continuous variable (Spearman $\rho=$ $-0.09, p=0.24)$.

The initial linear model revealed no effect of florbetapir $(p=$ $0.64)$, but a significant effect of ApoE genotype $(p=0.007)$ and age $(p=0.008)$ on glucose metabolism, with the ApoE4 genotype and older age associated with lower glucose metabolism in the composite ROI. A second model added sex, MMSE score, ApoE2 genotype, and an ApoE4 $\times$ florbetapir interaction term. None of these additional model parameters were significantly associated with glucose metabolism, and there was no effect on the original results other than changes in $p$ values (for ApoE, $p=0.03$; for age, $p=0.01$; and for florbetapir, $p=0.98$ ). Glucose metabolism in the composite ROI, plotted as a function of ApoE genotype and florbetapir status, is shown in Figure 1.

In the voxelwise analyses, ApoE4 carriers compared to noncarriers showed reductions in metabolism throughout the entire brain. Figure 2 shows voxels that met a threshold of at least $p<$ 0.05 (uncorrected), with cluster peak voxels that met the $p<$ 0.001 cluster threshold shown in Table 2 . Some of these findings were in brain regions associated with metabolic reductions in $\mathrm{AD}$, such as the temporal and parietal cortex, but reductions were much more widespread, including both lateral and medial prefrontal cortex. While reductions were extensive, clusters that met criteria for significance were seen particularly in temporal, parietal, and frontal cortex. There were no regions in which ApoE4 carriers showed higher metabolism than noncarriers at $p<.05$ or lower. Contrasts of subject groups by florbetapir status revealed several small regions of increased metabolism in superior parietal cortex in florbetapir + subjects compared to florbetapir-, and several regions in temporal lobes in which the florbetapir- subjects showed greater metabolism. These regions were not significant using the cluster threshold.

\section{Discussion}

These data show a significant effect of ApoE4 genotype on cerebral glucose metabolism in aging that is not explained by the presence of fibrillar cerebral $\mathrm{A} \beta$ as detected by florbetapir binding. Florbetapir uptake was not associated with glucose hypometabolism, while both age and ApoE genotype were. Even after accounting for age effects, the presence of the ApoE4 allele remained associated with lower glucose metabolism. These results were seen in a pre-specified ROI analysis that sampled regions typically affected by $\mathrm{AD}$, and a whole-brain voxelwise analysis found widespread reductions in metabolism associated with the ApoE4 genotype. This adds to a growing list of functional brain abnormalities that are associated with the ApoE4 allele and do not appear mediated by fibrillar, aggregated forms of $\mathrm{A} \beta$.

The results from the ROI approach and the voxelwise approach require integration with one another. The ROIs sampled voxels that mainly showed metabolic reductions at the $p<0.05$ level. Because these ROIs targeted specific brain regions and were not corrected for multiple comparisons, they were highly sensitive in defining abnormalities. This ROI approach has been applied and found to be sensitive in different laboratories and different samples for the detection of AD (Landau et al., 2010; Caroli et al., 2012; Jack et al., 2012), but it is likely nonspecific for AD. Thus, the idea that these metabolic reductions represent presymptomatic $\mathrm{AD}$ is not necessarily supported by the widespread reductions seen in the whole-brain analysis. For the voxelwise analysis, the actual pattern of results depends on the significance threshold; widespread reductions are seen at the liberal $p<0.05$ level, but more restricted reductions are noted when using a cluster threshold. While neither set of whole-brain results defines voxels limited to regions typically affected by $\mathrm{AD}$, they are consistent with earlier studies showing widespread ApoE4 effects on metabolism (Reiman et al., 1996, 2004). Regardless of thresholding, there are numerous brain regions in which ApoE4 carriers show reductions compared to noncarriers, and no regions in which the reverse is seen. These findings are not restricted to the pattern of hypometabolism seen in patients with $\mathrm{AD}$.

The metabolic reductions in some of the association cortex, especially those seen on the medial surface in Figure 2, includes regions that in PET and $\mathrm{PMRI}$ studies are part of the default mode network (DMN), a network that is more active in the absence of externally presented stimuli and deactivates during externally driven cognitive engagement (Raichle et al., 2001). This network becomes disconnected in AD (Greicius et al., 2004) and in normal older people with evidence of $\mathrm{A} \beta$ deposition detected with another amyloid imaging agent, $\left[{ }^{11} \mathrm{C}\right] \mathrm{PIB}$ (Pittsburgh Compound B; Hedden et al., 2009; Mormino et al., 2011). It is also a region in which $\mathrm{A} \beta$ tends to be deposited (Buckner et al., 2005). However, neither the ApoE4 effects seen here, nor the pattern of $\mathrm{A} \beta$ deposition conforms specifically to the topography of the DMN (Buckner et al., 2009). Based on both the pattern of hypometabolism and its lack of association with aggregated $A \beta$, our results do not support an explanation whereby ApoE4 increases $\mathrm{A} \beta$ deposition in the $\mathrm{DMN}$, leading to $\mathrm{AD}$. Another possibility is that the widespread metabolic reductions seen throughout the brain of ApoE4 carriers confers vulnerability to other processes, 


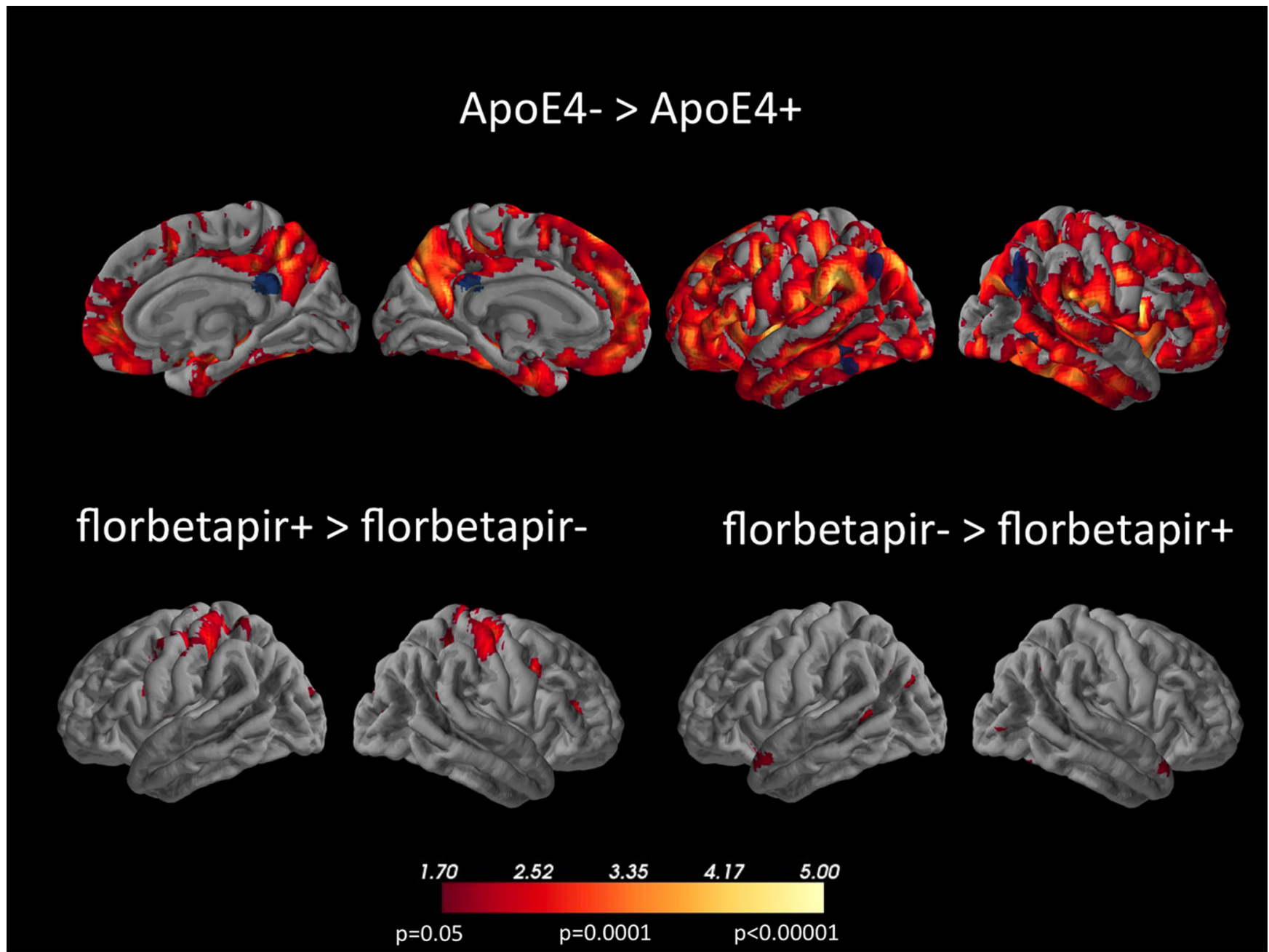

Figure 2. Results of whole brain voxelwise analysis showing three contrasts as indicated in the label. Lower threshold for all images is $t=1.70, p=0.05$ uncorrected, with brighter shades indicating higher $t$ and $p$ values as indicated. No significant voxels were found for the contrast ApoE4 $+>$ ApoE4-. The blue set of ROls represents the composite, pre-specified ROl as defined in the text. The peak voxels of clusters meeting the $p<0.001$ clusterwise criterion (see Materials and Methods) for the ApoE4 $->$ ApoE4 + contrast (top row) are listed in Table 2.

\section{Table 2. Hypometabolic regions for ApoE4 carriers relative to non-carriers}

\begin{tabular}{lrlrrr}
\hline \multicolumn{1}{c}{$k$} & \multicolumn{1}{l}{$x$} & \multicolumn{1}{l}{$y$} & \multicolumn{1}{c}{$z$} \\
\hline Left inferior frontal gyrus & 383 & 4.8 & -30 & 44 & -2 \\
Right rolandic operculum & 653 & 4.6 & 42 & -28 & 20 \\
Left supramarginal gyrus & 1124 & 4.4 & -60 & -32 & 28 \\
Left middle occipital gyrus & 292 & 4.3 & -32 & -72 & 38 \\
Left fusiform gyrus & 314 & 4.1 & -34 & -30 & -16 \\
Left precentral gyrus & 232 & 4.0 & -24 & -24 & 58 \\
Right insula & 244 & 4.0 & 32 & 14 & -14 \\
Right fusiform gyrus & 222 & 3.8 & 40 & -16 & -20 \\
\hline
\end{tabular}

such as metabolic stress (Vaishnavi et al., 2010; Vlassenko et al., 2010), that are involved in the pathogenesis of $\mathrm{AD}$.

Other reports confirm an effect of the ApoE polymorphism on brain function that is independent of $A \beta$. An fMRI study examined the DMN in normal older subjects who were characterized as $\mathrm{A} \beta$ negative using PIB-PET (Sheline et al., 2010). Contrasts between ApoE4 carriers and noncarriers revealed multiple nodes in which connectivity was increased in the carriers relative to noncarriers, as well as areas where connectivity was decreased. Another recent report examined relationships between $\mathrm{A} \beta$, ApoE genotype, and cognition and found an interaction such that $A \beta$ had more deleterious effects on cognitive function in ApoE4 carriers (Kantarci et al., 2012), another indication of a genotypic effect on brain function in aging that is independent of the amount of $A \beta$. The numerous studies indicating hypometabolism (Reiman et al., 2004), brain atrophy (Shaw et al., 2007), and alterations in resting state connectivity and brain activation (Filippini et al., 2009) in young adults at ages well before likely fibrillar $\mathrm{A} \beta$ pathology support the idea of amyloid-independent effects on neural processes. Finally, ApoE has also been shown to have an effect on mitochondrial function, with young ApoE4 carriers without $\mathrm{A} \beta$ showing reduced cytochrome oxidase activity compared to noncarriers (Valla et al., 2010).

While the results of this study indicate that fibrillar, aggregated forms of $\mathrm{A} \beta$ are an unlikely cause of hypometabolism in ApoE4 carriers, $A \beta$ also occurs in soluble, oligomeric forms that may affect neural function and are not detected by PET imaging agents (Shankar et al., 2007; Walsh and Selkoe, 2007). Therefore, it is possible that there is undetected soluble $\mathrm{A} \beta$ in ApoE4 carriers that would account for the hypometabolism in this group. However, aggregated fibrillar forms of $\mathrm{A} \beta$ in amyloid plaques are accompanied by soluble $\mathrm{A} \beta$ in human brains (Klunk et al., 2005), and the concentration of soluble $\mathrm{A} \beta$ is correlated with $\mathrm{A} \beta$ plaque burden (Kuo et al., 1996). Thus, failure to find an association between fibrillar $\mathrm{A} \beta$ and hypometabolism cannot be explained by 
the absence of soluble $A \beta$. Second, a recent study of biomarkers in presymptomatic, dominantly inherited $\mathrm{AD}$ suggests that soluble $\mathrm{A} \beta$ may become elevated and then begin to decline 25 years before symptoms, before fibrillar aggregation can be detected in the brain (Bateman et al., 2012). These forms of $\mathrm{A} \beta$ could contribute to hypometabolism and yet go undetected with amyloid imaging agents. However, glucose hypometabolism was not seen at early time points, but only years later, well after $A \beta$ was detectable in fibrillar form with PET. ApoE4 also plays a role in enhancing the synaptotoxic effects of oligomeric forms of $A \beta$ (Koffie et al., 2012). While it seems unlikely that soluble $A \beta$ explains the hypometabolism in our study, we cannot definitively exclude that possibility. These data do not suggest that the risk for $\mathrm{AD}$ seen with the ApoE4 genotype is unrelated to $\mathrm{A} \beta$, as we confirmed the well-described association between ApoE4 and $\mathrm{A} \beta$ deposition (Morris et al., 2010; Rodrigue et al., 2012) that, along with other extensive data, certainly makes it likely that this is one pathway through which ApoE may exert its effects. However, these results indicate that more than one such ApoE-mediated route to $\mathrm{AD}$ is likely to exist.

A conceptual model that unifies these results with theories of $\mathrm{AD}$ pathogenesis has recently been proposed (Jagust and Mormino, 2011). This model builds upon the observation, made through extensive animal studies, that neural activity modulates the secretion of $\mathrm{A} \beta$ through synaptic exocytosis (Nitsch et al., 1993; Kamenetz et al., 2003; Cirrito et al., 2005). In young transgenic mice, neural activity is related to both $\mathrm{A} \beta$ release and later regional deposition of plaques (Bero et al., 2011). This has led to the conjecture that neural activity itself may play a role in $\mathrm{A} \beta$ deposition in humans, an idea supported by findings that $A \beta$ release parallels fluctuations in synaptic activity in human sleep/ wake cycles (Gilestro et al., 2009) and is associated with level of consciousness in coma (Brody et al., 2008). The ApoE4 genotype could play a role in this process by reducing neural efficiency. Mice expressing human ApoE4 display abnormalities of synaptic transmission and dendritic arborization (Wang et al., 2005), reduction in dendritic spines (Ji et al., 2003; Dumanis et al., 2009), and alterations in LTP (Trommer et al., 2004). Taken in conjunction with the human imaging data showing lower resting metabolism and greater activation in the brains of young ApoE4 carriers performing cognitive tasks (Reiman et al., 2004; Filippini et al., 2009; Dennis et al., 2010; Filippini et al., 2011), these findings raise the possibility that resting metabolic dysfunction due to either ApoE4-related synaptic alterations or mitochondrial energetics results in the necessity for increased synaptic activity that might lead to more $\mathrm{A} \beta$ release.

Finally, these data have implications for existing models of the $\mathrm{AD}$ pathological cascade, which suggest that $\mathrm{A} \beta$ deposition precedes synaptic dysfunction (Jack et al., 2010). Our results argue for the reverse, at least in ApoE4 carriers. Changes in glucose metabolism may reflect synaptic activity, because the majority of the energy budget of the neuron is devoted to signaling (Attwell and Laughlin, 2001), and because correlations between glucose metabolism and synaptic markers have been reported (Rocher et al., 2003). In studies of $A D$ and presymptomatic stages of $A D$ to date, it appears that $A \beta$ is detectable before metabolic decline (Lo et al., 2011). However, our ability to measure $A \beta$ in vivo is relatively new, so examination of changes in metabolism and brain function in individuals who might be at risk for $\mathrm{AD}$ but have no detectable $\mathrm{A} \beta$ is limited. Future studies of unaffected individuals with different risks for $\mathrm{AD}$ should expand our understanding of the sequence of events in the development of this disorder.

\section{References}

Attwell D, Laughlin SB (2001) An energy budget for signaling in the grey matter of the brain. J Cereb Blood Flow Metab 21:1133-1145. CrossRef Medline

Bateman RJ, Xiong C, Benzinger TL, Fagan AM, Goate A, Fox NC, Marcus DS, Cairns NJ, Xie X, Blazey TM, Holtzman DM, Santacruz A, Buckles V, Oliver A, Moulder K, Aisen PS, Ghetti B, Klunk WE, McDade E, Martins $\mathrm{RN}$, et al. (2012) Clinical and biomarker changes in dominantly inherited Alzheimer's disease. N Engl J Med 367:795-804. CrossRef Medline

Bero AW, Yan P, Roh JH, Cirrito JR, Stewart FR, Raichle ME, Lee JM, Holtzman DM (2011) Neuronal activity regulates the regional vulnerability to amyloid-beta deposition. Nat Neurosci 14:750-756. CrossRef Medline

Bookheimer SY, Strojwas MH, Cohen MS, Saunders AM, Pericak-Vance MA, Mazziotta JC, Small GW (2000) Patterns of brain activation in people at risk for Alzheimer's disease. N Engl J Med 343:450-456. CrossRef Medline

Braak H, Braak E (1997) Frequency of stages of Alzheimer-related lesions in different age categories. Neurobiol Aging 18:351-357. CrossRef Medline

Brody DL, Magnoni S, Schwetye KE, Spinner ML, Esparza TJ, Stocchetti N, Zipfel GJ, Holtzman DM (2008) Amyloid-beta dynamics correlate with neurological status in the injured human brain. Science 321:1221-1224. CrossRef Medline

Buckner RL, Snyder AZ, Shannon BJ, LaRossa G, Sachs R, Fotenos AF, Sheline YI, Klunk WE, Mathis CA, Morris JC, Mintun MA (2005) Molecular, structural, and functional characterization of Alzheimer's disease: evidence for a relationship between default activity, amyloid, and memory. J Neurosci 25:7709-7717. CrossRef Medline

Buckner RL, Sepulcre J, Talukdar T, Krienen FM, Liu H, Hedden T, AndrewsHanna JR, Sperling RA, Johnson KA (2009) Cortical hubs revealed by intrinsic functional connectivity: mapping, assessment of stability, and relation to Alzheimer's disease. J Neurosci 29:1860-1873. CrossRef Medline

Cao J, Worsley KJ (2001) Applications of random fields in human brain mapping. In: Spatial statistics: methodological aspects and applications (Moore M, ed), pp 169-182. New York: Springer.

Caroli A, Prestia A, Chen K, Ayutyanont N, Landau SM, Madison CM, Haense C, Herholz K, Nobili F, Reiman EM, Jagust WJ, Frisoni GB (2012) Summary metrics to assess Alzheimer disease-related hypometabolic pattern with 18F-FDG PET: head-to-head comparison. J Nucl Med 53:592-600. CrossRef Medline

Castellano JM, Kim J, Stewart FR, Jiang H, DeMattos RB, Patterson BW, Fagan AM, Morris JC, Mawuenyega KG, Cruchaga C, Goate AM, Bales KR, Paul SM, Bateman RJ, Holtzman DM (2011) Human apoE isoforms differentially regulate brain amyloid-beta peptide clearance. Sci Transl Med 3:89ra57. CrossRef Medline

Cirrito JR, Yamada KA, Finn MB, Sloviter RS, Bales KR, May PC, Schoepp DD, Paul SM, Mennerick S, Holtzman DM (2005) Synaptic activity regulates interstitial fluid amyloid-beta levels in vivo. Neuron 48:913-922. CrossRef Medline

Clark CM, Schneider JA, Bedell BJ, Beach TG, Bilker WB, Mintun MA, Pontecorvo MJ, Hefti F, Carpenter AP, Flitter ML, Krautkramer MJ, Kung HF, Coleman RE, Doraiswamy PM, Fleisher AS, Sabbagh MN, Sadowsky CH, Reiman PE, Zehntner SP, Skovronsky DM (2011) Use of florbetapir-PET for imaging beta-amyloid pathology. JAMA 305:275-283. CrossRef Medline

Corder EH, Saunders AM, Strittmatter WJ, Schmechel DE, Gaskell PC, Small GW, Roses AD, Haines JL, Pericak-Vance MA (1993) Gene dose of apolipoprotein E type 4 allele and the risk of Alzheimer's disease in late onset families. Science 261:921-923. CrossRef Medline

Dennis NA, Browndyke JN, Stokes J, Need A, Burke JR, Welsh-Bohmer KA, Cabeza R (2010) Temporal lobe functional activity and connectivity in young adult APOE varepsilon4 carriers. Alzheimers Dement 6:303-311. CrossRef Medline

Dumanis SB, Tesoriero JA, Babus LW, Nguyen MT, Trotter JH, Ladu MJ, Weeber EJ, Turner RS, Xu B, Rebeck GW, Hoe HS (2009) ApoE4 decreases spine density and dendritic complexity in cortical neurons in vivo. J Neurosci 29:15317-15322. CrossRef Medline

Filippini N, MacIntosh BJ, Hough MG, Goodwin GM, Frisoni GB, Smith SM, Matthews PM, Beckmann CF, Mackay CE (2009) Distinct patterns of brain activity in young carriers of the APOE-epsilon4 allele. Proc Natl Acad Sci U S A 106:7209-7214. CrossRef Medline

Filippini N, Ebmeier KP, MacIntosh BJ, Trachtenberg AJ, Frisoni GB, Wilcock GK, Beckmann CF, Smith SM, Matthews PM, Mackay CE (2011) 
Differential effects of the APOE genotype on brain function across the lifespan. Neuroimage 54:602-610. CrossRef Medline

Fleisher AS, Chen K, Liu X, Roontiva A, Thiyyagura P, Ayutyanont N, Joshi AD, Clark CM, Mintun MA, Pontecorvo MJ, Doraiswamy PM, Johnson KA, Skovronsky DM, Reiman EM (2011) Using positron emission tomography and florbetapir F18 to image cortical amyloid in patients with mild cognitive impairment or dementia due to Alzheimer disease. Arch Neurol 68:1404-1411. CrossRef Medline

Gilestro GF, Tononi G, Cirelli C (2009) Widespread changes in synaptic markers as a function of sleep and wakefulness in Drosophila. Science 324:109-112. CrossRef Medline

Greicius MD, Srivastava G, Reiss AL, Menon V (2004) Default-mode network activity distinguishes Alzheimer's disease from healthy aging: evidence from functional MRI. Proc Natl Acad Sci U S A 101:4637-4642. CrossRef Medline

Hedden T, Van Dijk KR, Becker JA, Mehta A, Sperling RA, Johnson KA, Buckner RL (2009) Disruption of functional connectivity in clinically normal older adults harboring amyloid burden. J Neurosci 29:1268612694. CrossRef Medline

Jack CR Jr, Knopman DS, Jagust WJ, Shaw LM, Aisen PS, Weiner MW, Petersen RC, Trojanowski JQ (2010) Hypothetical model of dynamic biomarkers of the Alzheimer's pathological cascade. Lancet Neurol 9:119-128. CrossRef Medline

Jack CR Jr, Knopman DS, Weigand SD, Wiste HJ, Vemuri P, Lowe V, Kantarci K, Gunter JL, Senjem ML, Ivnik RJ, Roberts RO, Rocca WA, Boeve BF, Petersen RC (2012) An operational approach to National Institute on Aging-Alzheimer's Association criteria for preclinical Alzheimer disease. Ann Neurol 71:765-775. CrossRef Medline

Jagust WJ, Mormino EC (2011) Lifespan brain activity, beta-amyloid, and Alzheimer's disease. Trends Cogn Sci 15:520-526. CrossRef Medline

Jagust WJ, Landau SM, Shaw LM, Trojanowski JQ, Koeppe RA, Reiman EM, Foster NL, Petersen RC, Weiner MW, Price JC, Mathis CA (2009) Relationships between biomarkers in aging and dementia. Neurology 73: 1193-1199. CrossRef Medline

Jagust WJ, Bandy D, Chen K, Foster NL, Landau SM, Mathis CA, Price JC, Reiman EM, Skovronsky D, Koeppe RA (2010) The Alzheimer's Disease Neuroimaging Initiative positron emission tomography core. Alzheimers Dement 6:221-229. CrossRef Medline

Ji Y, Gong Y, Gan W, Beach T, Holtzman DM, Wisniewski T (2003) Apolipoprotein $\mathrm{E}$ isoform-specific regulation of dendritic spine morphology in apolipoprotein E transgenic mice and Alzheimer's disease patients. Neuroscience 122:305-315. CrossRef Medline

Joshi AD, Pontecorvo MJ, Clark CM, Carpenter AP, Jennings DL, Sadowsky CH, Adler LP, Kovnat KD, Seibyl JP, Arora A, Saha K, Burns JD, Lowrey MJ, Mintun MA, Skovronsky DM (2012) Performance characteristics of amyloid PET with florbetapir F 18 in patients with Alzheimer's disease and cognitively normal subjects. J Nucl Med 53:378-384. CrossRef Medline

Kamenetz F, Tomita T, Hsieh H, Seabrook G, Borchelt D, Iwatsubo T, Sisodia S, Malinow R (2003) APP processing and synaptic function. Neuron 37:925-937. CrossRef Medline

Kantarci K, Lowe V, Przybelski SA, Weigand SD, Senjem ML, Ivnik RJ, Preboske GM, Roberts R, Geda YE, Boeve BF, Knopman DS, Petersen RC, Jack CR Jr (2012) APOE modifies the association between Abeta load and cognition in cognitively normal older adults. Neurology 78:232-240. CrossRef Medline

Kim J, Basak JM, Holtzman DM (2009) The role of apolipoprotein E in Alzheimer's disease. Neuron 63:287-303. CrossRef Medline

Klunk WE, Lopresti BJ, Ikonomovic MD, Lefterov IM, Koldamova RP, Abrahamson EE, Debnath ML, Holt DP, Huang GF, Shao L, DeKosky ST, Price JC, Mathis CA (2005) Binding of the positron emission tomography tracer Pittsburgh compound-B reflects the amount of amyloid-beta in Alzheimer's disease brain but not in transgenic mouse brain. J Neurosci 25:10598-10606. CrossRef Medline

Koffie RM, Hashimoto T, Tai HC, Kay KR, Serrano-Pozo A, Joyner D, Hou S, Kopeikina KJ, Frosch MP, Lee VM, Holtzman DM, Hyman BT, SpiresJones TL (2012) Apolipoprotein E4 effects in Alzheimer's disease are mediated by synaptotoxic oligomeric amyloid- $\beta$. Brain 135:2155-2168. CrossRef Medline

Kok E, Haikonen S, Luoto T, Huhtala H, Goebeler S, Haapasalo H, Karhunen PJ (2009) Apolipoprotein E-dependent accumulation of Alzheimer disease-related lesions begins in middle age. Ann Neurol 65:650-657. CrossRef Medline

Kuo YM, Emmerling MR, Vigo-Pelfrey C, Kasunic TC, Kirkpatrick JB, Murdoch GH, Ball MJ, Roher AE (1996) Water-soluble Abeta (N-40, N-42) oligomers in normal and Alzheimer disease brains. J Biol Chem 271:40774081. CrossRef Medline

Lacor PN, Buniel MC, Furlow PW, Clemente AS, Velasco PT, Wood M, Viola KL, Klein WL (2007) Abeta oligomer-induced aberrations in synapse composition, shape, and density provide a molecular basis for loss of connectivity in Alzheimer's disease. J Neurosci 27:796-807. CrossRef Medline

Landau SM, Harvey D, Madison CM, Reiman EM, Foster NL, Aisen PS, Petersen RC, Shaw LM, Trojanowski JQ, Jack CR Jr, Weiner MW, Jagust WJ (2010) Comparing predictors of conversion and decline in mild cognitive impairment. Neurology 75:230-238. CrossRef Medline

Landau SM, Harvey D, Madison CM, Koeppe RA, Reiman EM, Foster NL, Weiner MW, Jagust WJ (2011) Associations between cognitive, functional, and FDG-PET measures of decline in AD and MCI. Neurobiol Aging 32:1207-1218. CrossRef Medline

Landau SM, Mintun MA, Joshi AD, Koeppe RA, Petersen RC, Aisen PS, Weiner MW, Jagust WJ (2012) Amyloid deposition, hypometabolism, and longitudinal cognitive decline. Ann Neurol 72:578-586. CrossRef Medline

Levi O, Jongen-Relo AL, Feldon J, Roses AD, Michaelson DM (2003) ApoE4 impairs hippocampal plasticity isoform-specifically and blocks the environmental stimulation of synaptogenesis and memory. Neurobiol Dis 13:273-282. CrossRef Medline

Lind J, Persson J, Ingvar M, Larsson A, Cruts M, Van Broeckhoven C, Adolfsson R, Bäckman L, Nilsson LG, Petersson KM, Nyberg L (2006) Reduced functional brain activity response in cognitively intact apolipoprotein E epsilon4 carriers. Brain 129:1240-1248. CrossRef Medline

Lo RY, Hubbard AE, Shaw LM, Trojanowski JQ, Petersen RC, Aisen PS, Weiner MW, Jagust WJ (2011) Longitudinal change of biomarkers in cognitive decline. Arch Neurol 68:1257-1266. CrossRef Medline

Ma J, Yee A, Brewer HB Jr, Das S, Potter H (1994) Amyloid-associated proteins alpha 1-antichymotrypsin and apolipoprotein E promote assembly of Alzheimer beta-protein into filaments. Nature 372:92-94. CrossRef Medline

Mormino EC, Smiljic A, Hayenga AO, Onami SH, Greicius MD, Rabinovici GD, Janabi M, Baker SL, Yen IV, Madison CM, Miller BL, Jagust WJ (2011) Relationships between beta-amyloid and functional connectivity in different components of the default mode network in aging. Cereb Cortex 21:2399-2407. CrossRef Medline

Morris JC (1993) The clinical dementia rating (CDR): current version and scoring rules. Neurology 43:2412-2414. CrossRef Medline

Morris JC, Roe CM, Xiong C, Fagan AM, Goate AM, Holtzman DM, Mintun MA (2010) APOE predicts amyloid-beta but not tau Alzheimer pathology in cognitively normal aging. Ann Neurol 67:122-131. CrossRef Medline

Näslund J, Thyberg J, Tjernberg LO, Wernstedt C, Karlström AR, Bogdanovic N, Gandy SE, Lannfelt L, Terenius L, Nordstedt C (1995) Characterization of stable complexes involving apolipoprotein $\mathrm{E}$ and the amyloid beta peptide in Alzheimer's disease brain. Neuron 15:219-228. CrossRef Medline

Nitsch RM, Farber SA, Growdon JH, Wurtman RJ (1993) Release of amyloid beta-protein precursor derivatives by electrical depolarization of rat hippocampal slices. Proc Natl Acad Sci U S A 90:5191-5193. CrossRef Medline

Raichle ME, MacLeod AM, Snyder AZ, Powers WJ, Gusnard DA, Shulman GL (2001) A default mode of brain function. Proc Natl Acad Sci U S A 98:676-682. CrossRef Medline

Rebeck GW, Reiter JS, Strickland DK, Hyman BT (1993) Apolipoprotein E in sporadic Alzheimer's disease: allelic variation and receptor interactions. Neuron 11:575-580. CrossRef Medline

Reiman EM, Caselli RJ, Yun LS, Chen K, Bandy D, Minoshima S, Thibodeau SN, Osborne D (1996) Preclinical evidence of Alzheimer's disease in persons homozygous for the e4 allele for apolipoprotein E. N Engl J Med 334:752-758. CrossRef Medline

Reiman EM, Chen K, Alexander GE, Caselli RJ, Bandy D, Osborne D, Saunders AM, Hardy J (2004) Functional brain abnormalities in young 
adults at genetic risk for late-onset Alzheimer's dementia. Proc Natl Acad Sci U S A 101:284-289. CrossRef Medline

Reiman EM, Chen K, Liu X, Bandy D, Yu M, Lee W, Ayutyanont N, Keppler J, Reeder SA, Langbaum JB, Alexander GE, Klunk WE, Mathis CA, Price JC, Aizenstein HJ, DeKosky ST, Caselli RJ (2009) Fibrillar amyloid-beta burden in cognitively normal people at 3 levels of genetic risk for Alzheimer's disease. Proc Natl Acad Sci U S A 106:6820-6825. CrossRef Medline

Rocher AB, Chapon F, Blaizot X, Baron JC, Chavoix C (2003) Resting-state brain glucose utilization as measured by PET is directly related to regional synaptophysin levels: a study in baboons. Neuroimage 20:1894-1898. CrossRef Medline

Rodrigue KM, Kennedy KM, Devous MD Sr, Rieck JR, Hebrank AC, DiazArrastia R, Mathews D, Park DC (2012) beta-Amyloid burden in healthy aging: Regional distribution and cognitive consequences. Neurology 78:387-395. CrossRef Medline

Schellenberg GD (1995) Genetic dissection of Alzheimer disease, a heterogeneous disorder. Proc Natl Acad Sci U S A 92:8552-8559. CrossRef Medline

Schmechel DE, Saunders AM, Strittmatter WJ, Crain BJ, Hulette CM, Joo SH, Pericak-Vance MA, Goldgaber D, Roses AD (1993) Increased amyloid beta-peptide deposition in cerebral cortex as a consequence of apolipoprotein E genotype in late-onset Alzheimer disease. Proc Natl Acad Sci U S A 90:9649-9653. CrossRef Medline

Shankar GM, Bloodgood BL, Townsend M, Walsh DM, Selkoe DJ, Sabatini BL (2007) Natural oligomers of the Alzheimer amyloid-beta protein induce reversible synapse loss by modulating an NMDA-type glutamate receptor-dependent signaling pathway. J Neurosci 27:2866-2875. CrossRef Medline

Shaw P, Lerch JP, Pruessner JC, Taylor KN, Rose AB, Greenstein D, Clasen L, Evans A, Rapoport JL, Giedd JN (2007) Cortical morphology in children and adolescents with different apolipoprotein E gene polymorphisms: an observational study. Lancet Neurol 6:494-500. CrossRef Medline

Sheline YI, Morris JC, Snyder AZ, Price JL, Yan Z, D’Angelo G, Liu C, Dixit S, Benzinger T, Fagan A, Goate A, Mintun MA (2010) APOE4 allele disrupts resting state fMRI connectivity in the absence of amyloid plaques or decreased CSF Abeta42. J Neurosci 30:17035-17040. CrossRef Medline

Silverman DH, Small GW, Chang CY, Lu CS, Kung De Aburto MA, Chen W,
Czernin J, Rapoport SI, Pietrini P, Alexander GE, Schapiro MB, Jagust WJ, Hoffman JM, Welsh-Bohmer KA, Alavi A, Clark CM, Salmon E, de Leon MJ, Mielke R, Cummings JL, et al. (2001) Positron emission tomography in evaluation of dementia: Regional brain metabolism and long-term outcome. JAMA 286:2120-2127. CrossRef Medline

Slezak M, Pfrieger FW (2003) New roles for astrocytes: regulation of CNS synaptogenesis. Trends Neurosci 26:531-535. CrossRef Medline

Small GW, Mazziotta JC, Collins MT, Baxter LR, Phelps ME, Mandelkern MA, Kaplan A, La Rue A, Adamson CF, Chang L, Guze BH, Corder EH, Saunders AM, Haines JL, Pericak-Vance MA, Roses AD (1995) Apolipoprotein E type 4 allele and cerebral glucose metabolism in relatives at risk for familial Alzheimer's disease. JAMA 273:942-947. CrossRef Medline

Trachtenberg AJ, Filippini N, Mackay CE (2012) The effects of APOEepsilon4 on the BOLD response. Neurobiol Aging 33:323-334. CrossRef Medline

Trommer BL, Shah C, Yun SH, Gamkrelidze G, Pasternak ES, Ye GL, Sotak M, Sullivan PM, Pasternak JF, LaDu MJ (2004) ApoE isoform affects LTP in human targeted replacement mice. Neuroreport 15:2655-2658. CrossRef Medline

Vaishnavi SN, Vlassenko AG, Rundle MM, Snyder AZ, Mintun MA, Raichle ME (2010) Regional aerobic glycolysis in the human brain. Proc Natl Acad Sci U S A 107:17757-17762. CrossRef Medline

Valla J, Yaari R, Wolf AB, Kusne Y, Beach TG, Roher AE, Corneveaux JJ, Huentelman MJ, Caselli RJ, Reiman EM (2010) Reduced posterior cingulate mitochondrial activity in expired young adult carriers of the APOE epsilon4 allele, the major late-onset Alzheimer's susceptibility gene. J Alzheimers Dis 22:307-313. CrossRef Medline

Vlassenko AG, Vaishnavi SN, Couture L, Sacco D, Shannon BJ, Mach RH, Morris JC, Raichle ME, Mintun MA (2010) Spatial correlation between brain aerobic glycolysis and amyloid-beta (Abeta) deposition. Proc Natl Acad Sci U S A 107:17763-17767. CrossRef Medline

Walsh DM, Selkoe DJ (2007) A beta oligomers - a decade of discovery. J Neurochem 101:1172-1184. CrossRef Medline

Wang C, Wilson WA, Moore SD, Mace BE, Maeda N, Schmechel DE, Sullivan PM (2005) Human apoE4-targeted replacement mice display synaptic deficits in the absence of neuropathology. Neurobiol Dis 18:390-398. CrossRef Medline 